\title{
Corporate Restructuring in Vietnam: An Analysis of Asset Restructuring
}

\author{
SU DINH THANH \\ University of Economics HCMC - dinhthanh@ueh.edu.vn \\ DOAN VU NGUYEN \\ Trường Cao đẳng Tài chính - Hải quan - doanvunguyen89@gmail.com \\ BUI THANH TRUNG \\ University of Economics HCMC - trungbt@ueh.edu.vn
}

\section{ARTICLE INFO ABSTRACT}

Article history:

Received:

Sep. 222015

Received in revised form:

Dec. 252015

Accepted:

June 202016

Keywords:

corporate restructuring, performance, logit and probit and GMM models.
Corporate restructuring is likely to be approached from various aspects. In this paper and in the context of Vietnam, it is inspected via asset restructuring. Using both financial and non-financial indicators of 226 listed firms on Hochiminh Stock Exchange (HOSE) and Hanoi Stock Exchange (HNX) over the 2007-2014 period, this paper investigates: (i) the determinants of corporate restructuring in Vietnam; and (ii) the effects of corporate restructuring on corporate performance. Empirical findings show that: (i) the fact that an enterprise conducts its restructuring plans primarily depends on its performance, and ownership concentration has a negative impact on the process of restructuring; (ii) a board with the presence of outside directors has positive and statistically significant effects on the performance of the firm, and foreign holdings lead to subsequent performance improvement. 


\section{Introduction}

Since 'Doi moi' (an innovation process in Vietnam) the country has attained remarkable economic growth, foreign trade expansion, improvements in foreign investment attraction, poverty reduction, and human development. In line with the country's economic reform and development, Vietnam's private enterprises have witnessed significantly growth, especially since 2000 to date and after the promulgation of the Enterprise Law. In 2014, Vietnamese private firms accounted for nearly $80 \%$ of the total number of enterprises with employment making up about $44 \%$ of the total. However, the majority (around 90\%) of the registered private companies are small- and medium-sized enterprises (SMEs) (GSO, 2013). Despite these impressive achievements, Vietnam's private enterprises remain weak in terms of internal and external networking, competitiveness, innovativeness, human resources, and readiness to globalization. Recent studies have reported that private SMEs have difficulties in getting access to such resources as land and financing for further development (Cuong et al., 2007; JBIC, 2003). The process of state-owned enterprises (SOEs) reform in Vietnam in the 1980s, which was a radical shift from a centrally planned economy to a market-oriented one, has resulted in many notable attainments. However, the SOEs sector has been viewed as less competitive and effective as compared to the private one since the focus of the restructuring process was merely on small-sized SOEs. The capital for equitization accounted for only $65 \%$ of total state capital among SOEs until 2015. These figures imply that after nearly 30 years of transformation toward a socialist-oriented market economy, a significant, distinctive state sector remains in Vietnam.

In the context of integration into ASEAN Economic Community (AEC) and participation in Trans-Pacific Partnership (TPP) Agreement, Vietnamese businesses are confronting with challenges in corporate governance and administration, such as lack of strategies, cash flow imbalances, human resource shortfalls, and improper operating systems. Thus, Vietnamese businesses must accelerate their restructuring processes as a response to radical changes in business environment caused by international and regional integration and changes in various laws. There are some studies on this issue. Vo et al. (2013) argued that Vietnam's privatized firms with less state ownership perform better than those with more state ownership. Tran et al. (2014) found that there is a negative effect of state ownership on firm profitability and labor productivity. Phung and Hoang (2013) stated that ownership has an inverted U-shaped relationship with firm 
performance, whereas foreign ownership has a U-shaped relationship with firm performance.

Corporate restructuring can be approached from various aspects. In this study, particularly, it is investigated via asset restructuring and through the examination of: (i) the determinants of corporate restructuring in Vietnam; and (ii) its effects on subsequent performance. We use both financial and non-financial indicators of 226 listed firms on HOSE (Ho Chi Minh Stock Exchange) and HNX (Hanoi Stock Exchange) over the period of 2007-2014. This paper also has another contribution by reshaping the misleading concepts of corporate restructuring in Vietnam: usually, it refers to a reduction in the state ownership at state-owned enterprises; however, such changes are not considered as corporate restructuring activities as suggested by existing literature about corporate restructuring.

This paper is organized as follows. The second section is the literature review. In the third section, an empirical model is presented. Econometric approaches are described in the fourth section, while in the fifth section we present data and variable measures. Empirical results are analyzed in the sixth section, followed by the final section with further discussion and conclusion.

\section{Literature review}

\subsection{Corporate restructuring background}

Corporate restructuring involves reorienting or refocusing a firm around its core product, business line, and geographical market (Hoskisson \& Turk, 1990; Markides, 1992). A firm decides to implement its restructuring schemes because of both internal and external factors, and it may choose to undertake either disciplinary or voluntary restructuring to make a recovery. Corporate restructuring can be divided into three different forms: portfolio, financial, and organizational (Bowman \& Singh, 1993). Portfolio restructuring refers to changes in a firm's mix of business so that the firm can focus on its core business. Organizational restructuring emphasizes on enhancing internal efficiency as an appropriate response to radical changes in business environment (Bowman \& Singh, 1993; Zajac \& Kraatz, 1993) through cost-cutting strategies (Lee \& Teo, 2005). Financial restructuring involves changes in the firm's financial structure such as increasing use of debt or dividend distribution (Jensen \& Meckling, 1976). The 
argument is that interest burdens have prevented managers from wasting cash flows on unrewarding diversification projects (Bowman \& Singh, 1993).

\subsection{Factors affecting inflation}

Two dominant explanations for what triggers corporate restructuring are: (i) agency theory; and (ii) business environment (Bethel \& Liebeskind, 1993; Johnson et al., 1993; Park \& Kim, 2008).

First, the agency theory argues that corporate restructuring is a correction for overexpansion or over-diversification after a period of steady increases in the size and scope of the firm. It states that managers, when acting as agents for shareholders, have little incentive to maximize the wealth of shareholders, but have more to increase their wealth. It is caused by the fact that the shareholders' wealth solely depends on share price, whereas managers' compensation is connected with the firm's profitability. Consequently, managers are likely to choose large projects with high risks although these investments do not lead to a sustainable increase in the shareholders' wealth. Hence, the misalignment of interest between managers and owners of a firm leads to a reduction in its value and profitability. Based on this theory, a stream of studies has focused on the importance of corporate governance, which is measured by ownership structure, the board independence, and the board composition, in initiating necessary restructuring activities to recover the firm's performance and value (Denis \& Kruse, 2000; Park \& Kim, 2008).

Business environment is the second dominant trigger of corporate restructuring (Bethel \& Liebeskind, 1993; Bowman \& Singh, 1993). Although performance enhancement is a profound motivation for voluntary restructuring, corporate restructuring can be forced by radical changes in business conditions, such as tax (Hoskisson \& Hitt, 1990), antitrust policy (Champlin \& Knoedler, 1999), or international commitment (Bleackley \& Williamson, 1997). Bergh (1998) concluded that strategies of portfolio restructuring rely on the uncertainty of the market. Refocusing, which is to acquire related businesses and divest unrelated ones, is appropriate when uncertainty is increasingly greater. However, diversifying activities is a further applicable response to a less uncertain market. Because managers rarely undertake necessary restructuring strategies to properly respond to business-environmental challenges without shareholders' threats, environmental explanation predicts a significant relationship between corporate restructuring and ownership structure (Bethel \& Liebeskind, 1993). 
Following these arguments, our paper emphasizes the ownership structure as a critical cause of corporate restructuring.

\subsubsection{Ownership structure and corporate performance}

Empirical studies have highlighted the importance of ownership structure in initiating corporate restructuring activities. As suggested by Bethel and Liebeskind (1993), there are three groups of shareholders that can induce corporate restructuring activities: insiders, controlling shareholders, and institutional investors.

An insider is a manager who holds shares of the firm. As predicted by the agency theory, managers who own substantial firm equity have greater incentive to maintain the interest alignment between them and other owners (Fama \& Jensen, 1983; Jensen \& Meckling, 1976). There is substantial evidence of the positive relation between corporate performance, which is measured by Tobin's Q or ROA, and managerial ownership (McConnell \& Servaes, 1990; Morck et al., 1988). Since managerial ownership is assumed to be an incentive alignment device, it may be negatively related to corporate diversification. Denis et al. (1997) argued that increasing managerial ownership may lower the level of corporate diversification. However, the entrenchment effect exists of the nexus between managerial ownership and corporate performance (Fama \& Jensen, 1983). At lower level of managerial ownership, market discipline enhances its role as an incentive alignment tool. However, when managers hold the majority of corporate equity, the external shareholders find it difficult to oversee them.

Controlling shareholders are those who have large shareholding in a firm. The existing studies are inclusive about the link between controlling shareholder and corporate restructuring. On the one hand, the agency theory assumes a negative link between the two variables (Bethel \& Liebeskind, 1993). Controlling shareholders may act as whistle-blowers who will discipline an inefficient management. They have both power and incentive to effectively monitor the performance of firm management, and great ownership forces them to face substantial financial losses if the firm management undertakes unproductive projects. Moreover, greater voting power allows them to provide disciplines on the existing board of director and even ask for changing the constitution of the firm (Pound, 1991). Other shareholder activism may include proxy contest, precipitating a takeover (Shleifer \& Vishny, 1986), replacing the inefficient board of directors, and preventing managers from taking on excessive risks (Jensen, 1986). Therefore, a performance-declining corporation is more likely to restructure with 
the large shareholder's presence (Bethel \& Liebeskind, 1993). On the other hand, the "bird-in-hand" theory suggests a positive link between controlling shareholder and corporate performance. Jensen and Meckling (1976) reasoned that major shareholders prefer excessive dividend payouts, which is beneficial for the large shareholder but harmful for long-term development of a firm. However, board structure (Yeh \& Woidtke) and board independence (Claessens et al., 2000) can mitigate the entrenchment effect of controlling shareholders. In accordance with the "bird-in-hand" theory, the controlling shareholder may be positively related to corporate restructuring.

Institutional investors may affect corporate restructuring in similar ways to those of controlling shareholders. Despite not directly owning shares, they manage shares and sometimes make vote on behalf of their clients. Consequently, they act as a monitoring device that oversees the performance of the management and formulate any restructuring activities when a firm faces a reduction in its performance. Significant institutional shareholding motivates the active role of the board in maximizing the firm value. Moreover, for beating the market, they actively influence the managerial policy and create long-term orientation in policy designing (Hansen \& Hill, 1991). Kang and Shivdasani (1997) claimed that institutional ownership may increase the probability of replacing the inefficient board and management. An increase in institutional ownership may lower the level of corporate diversification (Chen \& Yu, 2012). Kang and Shivdasani (1997) noted that main bank ownership and blockholder ownership are positively related to firm downsizing.

2.2.2. Other determinants of corporate restructuring: performance, board, and capital structure

Although corporate restructuring is primarily triggered by ownership structure, its likelihood is dependent on firm performance (John et al., 1992; Kang \& Shivdasani, 1997; Lai \& Sudarsanam, 1997). John et al. (1992) found that firms with declining performance reduce about $5 \%$ of their staffs in addition to decreasing its $\mathrm{R} \& \mathrm{D}$ investment and debt usage. Empirical studies have proven that a firm where the board of directors has adequate powers is likely to undergo restructuring (Bethel \& Liebeskind, 1993; Gibbs, 1993; Lai \& Sudarsanam, 1997). Although corporate restructuring is often undertaken as a response to a steady decline in firm performance, such restructuring will not occur without the pressures from a strong board (Perry \& Shivdasani, 2005). As an incentive alignment tool, board independence promotes asset downsizing when the firm 
encounters value-declining events such as a sustainable decline in performance (Paul, 2007).

The extant literature employs several proxies for board independence: (i) the percentage of outside directors on the board (Ghosh \& Sirmans, 2003), (ii) the ratio of the average tenure of outside directors to the average tenure of CEO (Ghosh \& Sirmans, 2003); and (iii) the diversity of the board (Carter et al., 2003). Generally, a board with a majority of outside directors is more independent due to the monitoring activities of outside directors. A CEO with longer tenure has both time and opportunity to accumulate his or her shareholdings. Higher CEO ownership may render the monitoring role of outside directors on the board (Ghosh \& Sirmans, 2003). As observed by Carter et al. (2003), a board, whose members are different in terms of gender, ethnics, and background, may improve its independence. It is useful to consider the impact of board composition on the firm's performance and restructuring. Firms whose boards members are mostly outsiders are twice as likely to respond with operational actions, including asset restructuring and employee layoffs or other cost-cutting initiatives (Perry \& Shivdasani, 2005).

A higher level of debt usage, or financial leverage, increases the probability that a firm implements capital restructuring (Ofek, 1993; Pandey \& Ongpipattanakul, 2015). Lai and Sudarsanam (1997) predicted a positive link between debt usage and all restructuring activities. There are several channels through which debt usage is linked to corporate restructuring activities. First, debt reduces the agency costs of cash flows and prevents a firm's managers from exploiting its resources (Jensen, 1986). Creditors guarantee their promised payments by including restricted covernants in the indenture provisions, which prevent misconducts of firm managers through constraints established on their decisions such as dividend payout, debt issues, and working capital management. Second, investors may detect important information by investigating the ability of a firm to satisfy any claims associated with debt issues until maturity. Both timing and quantity of debt repayment can be used to access the efficiency of a firm's management and its business strategy (Harris \& Raviv, 1990). Finally, managers can use debt as a device to prevent takeovers (Harris \& Raviv, 1988).

\subsection{Corporate restructuring and its performance-improving effects}

Following the existing literature, this paper centers on portfolio restructuring, which is measured by asset restructuring. Asset divestiture is a basic strategy to lower the level 
of corporate diversification and enhance corporate performance. Among a variety of strategies, asset divestiture and employee layoffs are fundamental to refocus the firm on its core business. Empirical studies have detected the positive effects of corporate divestiture on subsequent performance (Dittmar \& Shivdasani, 2003; Lee \& Madhavan, 2010; Sun, 2012). Comment and Jarrell (1995) explained that the divestiture program orients the firm to its efficient assets and thus improves its performance. Dittmar and Shivdasani (2003) proved that a firm becomes more efficient in making segment investment when it is getting more focused. De Meuse et al. (2004) investigated whether the financial performance of firms changes before, during, and after the incidence of employment layoffs. They showed that the firm's performance follows a J-curve in which it is lackluster during a couple of initial years and then becomes improved. Brauer and Laamanen (2014) distinguished the effects of employment downsizing at different scales on efficiency improvement. Their study suggested that both small-scale and largescale downsizing have positive impacts on firm performance, whereas medium-scale downsizing has no performance-improving effects. These scholars' findings also point out that employment downsizing on a small scale has no damage on the existing routine of the firm whereas the large-scale requires a recreation of routines.

\section{Empirical model}

Following previous studies (Denis \& Kruse, 2000; Kang \& Shivdasani, 1997; Paul, 2007; Perry \& Shivdasani, 2005), we employ equations as follows:

Eq. 1 is used to estimate determinants of corporate restructuring:

$$
R E S_{i t}=\delta_{0}+\delta_{1} P_{i t}+\delta_{2} O W S_{i t}+\delta_{3} B O S_{i t}+\delta_{4} Z_{i t}+\left(\theta_{i}+\xi_{i t}\right)
$$

Eq. 2 is to test impacts of corporate restructuring on corporate performance:

$$
P_{i t}=\beta_{0}+\beta_{1} R E S_{i t}+\beta_{2} O W S_{i t}+\beta_{3} B O S_{i t}+\beta_{4} Z+\left(\gamma_{i}+\zeta_{i t}\right)
$$

where:

- $\mathrm{i}=1,2, . ., \mathrm{N} ; \mathrm{t}=1,2, \ldots, \mathrm{T} . \mathrm{N}$ and $\mathrm{T}$ are the cross-section and time dimensions of the panel, respectively; $\theta_{i}$ is a fixed effect specific to firm $i$, and errors are independent, identically distributed, $\xi_{i t} \sim$ i.i.d $\left(0, \sigma_{\xi}\right), E\left(\theta_{i} / \xi_{i t}\right)=0$. Similarly, $\gamma_{i}$ is 
a fixed effect specific to firm $i$, and errors are independent, identically distributed $\zeta_{i t} \sim$ i.i.d $\left(0, \sigma_{\zeta}\right), E\left(\gamma_{i} / \zeta_{i t}\right)=0$.

- RES is the variable of corporate restructuring. If changes in a firm's assets are larger than 5\%, the firm is considered as restructuring (Perry \& Shivdasani, 2005). RES is measured by a dummy variable: 1 (corporate restructuring) and 0 (corporate non-restructuring).

- P is a set of variables that measures the performance of a firm. In this study, we use ROA and Tobin's $\mathrm{Q}$ to measure firm performance. Two conventional measures of its are ROA and Tobin's Q (Dahya et al., 2008; Dahya \& McConnell, 2007; Shan \& McIver, 2011). As quoted by Shan and McIver (2011), ROA is an accountingbased measure and reflects backwards-looking information, whereas Tobin's Q is a market-based measure and captures investors forward-looking valuation perceptions. Claessens et al. (2003) clarified the short-run and long-run effects of restructuring on performance by using: ROA and Tobin's Q. For instance, restructuring may decrease profitability in the short run because of its increasing administrative and organizational complexities. In the long run, however, firms may manage the complexities and gain benefits from restructuring upsides such as synergy gains. The effect of restructuring on ROA measuring the current performance is negative, but its effect on Tobin's Q can be positive because Tobin's Q capitalizes expected future rents (Lindenberg \& Ross, 1981).

- OWS is a set of variables that indicates a firm's ownership structure. Ownership structure is considered a crucial determinant of corporate restructuring and subsequent performance of the firm. In this study, ownership structure is measured by: (i) ownership concentration that is proxied by the total holdings of shareholders with more than 5\% of the firm's share outstanding at the end of the year (OWN) or the ratio of shares owned by controlling shareholders that are largest three shareholders to total shares (CR3); and (ii) shares that are held by the firm's foreign investors (FOR), states (GOV), and managers (CEO). There is no consensus about the direction of the association between ownership structure and firm performance. The proportion of shares owned by controlling shareholders or CEO is negatively associated with performance (Fama \& Jensen, 1983; Lasfer, 2006). The relationship 
between foreign ownership and performance is positive, but it is not clear with respect to state ownership (Chen \& Al-Najjar, 2012; Mak \& Li, 2001).

- BOS is a set of variables that measures board structure, including:

+ BOA: number of all executive and non-executive directors in the board; it is used as a proxy for board size. Some empirical studies provide evidence that increased board size has a positive effect on firm performance (Hillman et al., 2000; Nicholson \& Kiel, 2007; Van den Berghe \& Levrau, 2004). Others demonstrated that there exists a negative relationship between board size and performance (Bhagat \& Black, 1999).

+ OUT: number of non-executive directors in the board; it measures the level of board independence. Two opposing opinions have emerged with regard to the impact of outside directors on firm performance: a positive view and a negative view. Empirical studies on the relationship between the ratio of outside directors and performance support both viewpoints (Cho \& Kim, 2007; Dharwadkar et al., 2000). Poorly performing firms may change their board composition by increasing outside directors to improve performance (Hermalin \& Weisbach, 1988; Jackling \& Johl, 2009). We assume that it is crucial to focus on and investigate extensively the association between independent directors and firm performance.

- $\mathrm{Z}$ is a set of control variables that reflects firm characteristics, including:

+ LEV: ratio of total liability to total assets. A higher leverage not only amplifies the firm's earning level but also increases the variability of earnings. A highly leveraged firm depends on external finance and thus may require more advice and monitoring from outside (Coles et al., 2008). It implies that highly leveraged companies are likely to have larger boards and more outside directors. The positive association between board structure and leverage is corroborated in several empirical studies (Coles et al., 2008; Guest, 2008; Linck et al., 2008).

+ AGE: number of years since the firm was incorporated. Given the impact of age, one stream of research suggested that matured firms are more experienced and thus enjoy superior performance (Stinchcombe \& March, 1965). Another stream of research, nevertheless, maintained that matured firms are slowly adjusted to 
changing business conditions; consequently, they are likely to reflect lower performance than younger and more agile firms (Baek et al., 2004).

+ CAS: ratio of cash holdings to the book value of total assets. Previous studies (Brush et al., 2000; Fama \& Jensen, 1983; Lang et al., 1991) argued that a total free cash flow positively influences sales growth and performance. When firms experience a great economic shock, they can either turn to external capital markets or internal cash flows or curtail new investments. Less financially constrained firms should, therefore, suffer fewer difficulties.

+ PRO: total profits before tax divided by total assets. Munisi et al. (2014) opined that profitability positively affects the decision of restructuring and the consequence of operational efficiency. We calculate the profitability measures based on gross returns because it better reflects quality of the investment decisions made by the manager.

+ GRO: percentage change in total year-to-year sales. Sales growth targets play a major role in the perceptions of enterprises. An emphasis on sales growth provides a useful and visible benchmark to motivate performance (Brush et al., 2000; Fukui \& Ushijima, 2007).

\section{Econometric approaches}

Eq. 1 shows the outcome of restructuring status, which can be estimated using a linear probability model or a probit/logit model. In statistics a linear probability model (LPM) is a special case of binomial regression. The model assumes a binary outcome $Y$, and its associated vector of explanatory variables $X$.

$$
P(\mathrm{Y}=1 \mid X=x)=\mathrm{x}^{\prime} \beta
$$

For this model, with the assumption $E\left(\mathrm{u}_{i}\right)=0$.

$E\left[Y \mid X_{1 i}\right]=P\left(Y=1 \mid X_{1 i}\right)=\beta_{0}+\beta_{1} X_{1 i}$

$\left[E\left[Y \mid X_{1 i}\right]=1 * p i+0 *\left(1-p_{1}\right)\right]=p_{1}$

where $0 \leq p_{i} \leq 1 ; 0 \leq E\left(Y \mid X_{l i}\right) \leq 1$ 
However, the LPM model can have drawbacks: (i) heteroskedasticity occurs; (ii) the error terms are not normally distributed; (iii) $\widehat{Y}_{l}$ can be outside the unit interval $[0,1]$; and (iv) the coefficient of determination is small. Therefore, a logit_or probit model is used instead. According to Maddala (1984), the logit model $p_{i}$ is defined by:

$$
p_{i}=\frac{e^{\beta_{0}+\beta_{1} X_{1 i}}}{1+e^{\beta_{0}+\beta_{1} X_{1 i}}}=\frac{e^{X_{1} \beta}}{1+e^{X_{1} \beta}}
$$

where $X=\left(1, X_{i}\right) ; X_{i}=\left(1, X_{1 i}\right) ; \beta^{\prime}=\left(\beta_{0}, \beta_{1}\right)$

In this model $p_{i}$ is a non-linear function of dependent variables. We can apply the maximum likelihood method to estimates $\beta$.

Implies $\hat{\beta}$, estimates $p_{i}=P\left(Y=1 \mid X_{i}\right)$ and $\widehat{p}_{\iota}=\frac{\exp \left(X_{i} \hat{B}\right)}{1+\exp \left(X_{i} \widehat{B}\right)}$

The influence of the dependent variable $\mathbf{X}_{\mathbf{k}}$ on $p_{i}$ can be calculated as:

$$
\frac{\partial}{\partial X_{k}} p_{i}=\frac{\exp \left(X_{i} \hat{B}\right)}{\left(1+\exp \left(X_{i} \hat{B}\right)\right)^{2}} \beta_{k}=p_{i}\left(1-p_{i}\right) \beta_{k}
$$

To motivate the probit model as a latent variable model, we suppose that there exists an auxiliary random variable:

$$
Y^{*}=X^{T} \beta+\varepsilon \quad \varepsilon \sim N(0,1)
$$

Then $\mathrm{Y}$ can be viewed as an indicator for whether this latent variable is positive:

$$
Y=\left\{\begin{array}{c}
1\left(Y^{*}>0 ;-\varepsilon<X^{T} \beta\right) \\
0
\end{array}\right.
$$

Two models are equivalent (by symmetry of the normal distribution):

$$
P(Y=1 \mid X)=P\left(Y^{*}>0\right)=P\left(\varepsilon<X^{T} \beta\right)=\Phi\left(X^{T} \beta\right)
$$

We employ generalized method of moments (GMM) to test Eq. 2. GMM method either corrects the heteroscedasticity or resolves the problems of autocorrelation and endogeneity by using lags and differences of variables (Arellano \& Bond, 1991; Arellano \& Bover, 1995; Blundell \& Bond, 2000). Baum et al. (2003) suggested that GMM method is supremely efficient compared to other traditional estimation methods. In the GMM estimation, the most widely used alternatives are the methods for dynamic panel data estimation including Arellano-Bond difference and Blundell-Bond system GMM. GMM methods are superior to the alternatives in dealing with endogneity, heteroscedasticity, and serial correlation. They are specifically designed to capture the 
joint endogeneity of some explanatory variables through the creation of a weighting matrix of internal instruments, which accounts for serial correlation and heteroscedasticity. The GMM estimation technique requires one set of instruments to handle endogeneity and another set to deal with the correlation between the lagged dependent variable and the error term. The instruments include suitable lags of the levels of endogenous variables and strictly exogenous regressors. This estimator can easily generate a great many instruments since all lags prior to period $T$ might be individually regarded as instruments.

However, the big problem of the Arellano-Bond differenced GMM estimator is that the variance of the estimates may increase asymptotically and create considerable bias. Blundell and Bond (1998) and Blundell et al. (2000) showed that estimation in first differences has a large bias and low precision, even in studies with a large number of individuals ( $\mathrm{N})$. The system GMM estimator is likely to present the best features in terms of small sample bias and precision. It requires moment conditions, which are specified on the regression errors. Under moment conditions it is assumed that the instruments are exogenous. For such the moments of the errors with the instruments equal zero. In the system GMM estimator we consider choosing instruments and regressors in each equation. An equation may be under-identified, exactly identified, and over-identified depending on whether the number of instruments in that equation is respectively less than, equal to, or greater than the number of regressors. Unfortunately, there is no guidance on how to determine the appropriate number of instruments (Roodman, 2009). However, the rule of thumb is that instruments should not outnumber individuals and/or countries.

In GMM the Sargan test has a null hypothesis that "the instruments are exogenous." Therefore, the higher the $p$-value of the Sargan statistic, the better it becomes. The Arellano-Bond test for autocorrelation has a null hypothesis that there exists no autocorrelation, and it is applied to differenced residuals. The test for AR(2) process in first differences usually rejects the null hypothesis. The test for $\operatorname{AR}(2)$ is more substantial since it detects autocorrelation in levels.

As a matter of fact, a certain econometric model solely employs a dependent variable. However, the model in this research in which the endogenous variables (dependent variables) are determined simultaneously is a typical case for the application of simultaneous equations. Technically, each of the endogenous variables, which are 
resolved through being exogenous or predetermined, can allow for simplified system equations. The equations do not contain any endogenous variables, yet it depends on the number of random classes of all equations. If the former researches cannot solve the equation coefficients of a structure from the estimates of the shortened equation's coefficients, it means that these models cannot be recognized or are deemed underidentified. A kind of structures can be estimated uniquely as a result of an exactly identified equation. Finally, if more than one structure estimate exists, the result becomes an over-identified equation.

If an equation is identified correctly, it is possible to apply indirect least squares in the event that the first estimate's shortened form is followed by a span of settlement of backward structure coefficients. Zellner and Theil (1962) proposed the three-stage least squares (3SLS) for the simultaneous equations model. This method is especially suitable to an over-identified equation. In the first stage each reduced form equation is evaluated, and the predicted endogenous value is stored. These values will then replace endogenous variables, and the structure equations are estimated. Nonetheless, during the calculation of residuals and standard errors, the true endogenous value is used instead of the predicted one. Once the structure estimates are obtained, it is able to get short hidden estimated forms through the predefined endogenous and exogenous variables. The shortened hidden estimated forms obtained are more efficient than direct shortened estimated ones since the 3SLS estimates consider the over-identified limits.

\section{Research data}

The data used in this study were obtained from corporate annual reports. We use both financial and non-financial indicators of 226 listed firms on HOSE and HNX over the 2007-2014 period. The sample of the listed firms does not include: (i) those operating in industries such as banking, insurance, and securities; (ii) those treated for manipulating account; (iii) those with negative rates of return for more than three years in a row; and (iv) those listed for less than eight years or after 2007. These exclusions ensure the reliabilities of the research data. Table 1 presents summary statistics for variables in the research model. 


\section{Table 1}

Description of variables

\begin{tabular}{|c|c|}
\hline Variable & Definition \\
\hline RES & $\begin{array}{l}\text { Restructuring dummy variable: } 1,0 \text { (RES }=1 \text { if percentage of change in firm's assets } \\
>=5 \% \text {; RES }=0 \text { if percentage of change in firm's assets }<5 \%)\end{array}$ \\
\hline DAS & Percentage of change in firm's assets \\
\hline ROA & Ratio of earnings before interest and tax to total assets \\
\hline TOQ & $\begin{array}{l}\text { Ratio of market value of assets to book value of assets, where the market value of } \\
\text { assets equals the sum of year-end market capitalization of tradable shares, the product } \\
\text { of net assets per share by the number of non-tradable shares, and the total amount of } \\
\text { net long- and short-term liabilities }\end{array}$ \\
\hline FOR & $\begin{array}{l}\text { Number of shares owned by foreign shareholders divided by total shares outstanding } \\
\text { at year end }\end{array}$ \\
\hline MAN & Number of shares owned by the CEO divided by total shares outstanding at year end \\
\hline GOV & $\begin{array}{l}\text { Number of shares owned by the government divided by total shares outstanding at } \\
\text { year end }\end{array}$ \\
\hline CR3 & Ratio of shares owned by three largest shareholders to total shares \\
\hline OWN & $\begin{array}{l}\text { Proportion of shares owned by shareholders who own at least } 5 \% \text { of all shares } \\
\text { outstanding at year end }\end{array}$ \\
\hline BOA & Number of all executive and non-executive directors \\
\hline OUT & Number of non-executive directors \\
\hline LEV & Ratio of book value of total debts to that of total assets \\
\hline PRO & Total profits before tax divided by total assets \\
\hline CAS & Ratio of cash holdings to book value of total assets \\
\hline AGE & Number of years since the firm was incorporated \\
\hline GRO & Percentage of change in total year-to-year sales \\
\hline
\end{tabular}

Table 2 provides descriptive statistics of the variables. The list documents headforemost restructuring variable (RES) by year of our sample period, which is assigned two values: 0 and 1 . The core dummy variable is based on the degree of change assets. The mean value of percentage of change in assets (DAS) is around $14.54 \%$, and 
deviation in standard, about $32.15 \%$. The average ROA is 0.09 , whereas Tobin' $\mathrm{Q}$ is 1.08. The average ownership concentration (OWN) is $41.97 \%$ with a standard deviation of $26.13 \%$. The relevant figures for the three largest shareholders (CR3) are $40.25 \%$ and $25.26 \%$ respectively. The average foreign ownership (FOR) is $9.47 \%$ with standard deviation of $13.70 \%$. The average managerial ownership (MAN) is approximately $3.68 \%$ among the firms. The result indicates that average government ownership (GOV) is $20.43 \%$ with the maximum of $100 \%$. The mean of the board size (BOA) and the outside directors (OUT) is about 4.94 and 3.04, respectively.

\section{Table 2}

Descriptive statistics of variables

\begin{tabular}{cccccc}
\hline Variable & Observation & Mean & $\begin{array}{c}\text { Standard } \\
\text { Deviation }\end{array}$ & Min & Max \\
\hline RES & 1582 & 0.673 & 0.469 & 0 & 1 \\
DAS & 1582 & 0.145 & 0.321 & -1.162 & 6.125 \\
ROA & 1808 & 0.091 & 0.097 & -0.647 & 0.662 \\
TOQ & 1808 & 1.079 & 0.822 & 0.001 & 20.933 \\
FOR & 1808 & 9.473 & 13.701 & 0 & 78 \\
MAN & 1808 & 3.683 & 9.383 & 0 & 59.883 \\
GOV & 1807 & 20.434 & 24.306 & 0 & 100 \\
CR3 & 1808 & 40.254 & 25.300 & 0 & 100 \\
OWN & 1808 & 41.975 & 26.134 & 0 & 100 \\
BOA & 1808 & 4.939 & 2.218 & 0 & 13 \\
OUT & 1808 & 3.039 & 1.779 & 0 & 11 \\
LEV & 1808 & 0.483 & 0.212 & 0.001 & 0.974 \\
PRO & 1802 & 0.254 & 4.213 & -5.751 & 175.639 \\
CAS & 1808 & 24.561 & 1.764 & 17.146 & 30.812 \\
AGE & 1808 & 2.765 & 3.398 & -7 & 14 \\
GRO & 1576 & 0.135 & 0.468 & -2.731 & 5.437 \\
\hline
\end{tabular}

Note: All variables are measured in book value unless otherwise noted. 


\section{Empirical results}

\subsection{Determinants of corporate restructuring}

The results for Eq. 1 using the binary estimation procedures are shown in Tables 3 and 4 . Table 3 presents estimated results using ROA as a proxy for performance. Table 4 presents estimated results with the employment of Tobin's Q. The results of linear probability model (LPM) are indicated in Columns 1 and 2 of Tables 3 and 4, respectively, both of which show the estimated results for the logit model, whereas those for the probit model are provided in Columns 5 and 6 of Tables 3 and 4.

Tables 3 and 4 also indicate that the effects of ROA and TOQ on restructuring are positive and significant at $1 \%$ level. These results are consistent with studies of D'Souza et al. (2007) and Jefferson and Su (2006). The results suggest that firms with higher performance have greater effects on restructuring. Regarding ownership structure (OWN and CR3), the coefficients of the variable OWN are negative and significant at $1 \%$ level, and so are those of the variable CR3. These results are similar to those of earlier studies (Cho \& Kim, 2007; Jefferson \& Su, 2006). The coefficients of OWN are significantly negative, implying that firms with lower concentrations are more likely to restructure (Baek et al., 2004; Perry \& Shivdasani, 2005). Moreover, the findings also provide evidence of a positive relation between restructuring and foreign ownership (FOR), which is in line with those of Anderson (1987) and D'Souza et al. (2005, 2007). The relationship between government ownership (GOV) and restructuring is insignificant, and those between restructuring (RES) and outside directors (OUT)/board size (BOA) are also insignificant. These are consistent with the findings of Claessens et al. (2003) and Fukui and Ushijima (2007), suggesting that board composition has no direct impact on the process of restructuring, but has indirect impact through performance.

\section{Table 3}

Binary models for the effect of ROA on restructuring

\begin{tabular}{lcccccc}
\hline \multirow{2}{*}{ Variable } & \multicolumn{2}{c}{ LPM } & \multicolumn{2}{c}{ LOGIT } & \multicolumn{2}{c}{ PROBIT } \\
\cline { 2 - 7 } & RES (1) & RES (2) & RES (3) & RES (4) & RES (5) & RES (6) \\
\hline ROA & $1.291 * * *$ & $1.289 * * *$ & $7.902 * * *$ & $7.893 * * *$ & $4.416^{* * * *}$ & $4.414 * * *$ \\
& $(0.151)$ & $(0.151)$ & $(1.031)$ & $(1.032)$ & $(0.569)$ & $(0.570)$ \\
OWN & $-0.001 * *$ & & $-0.006 * *$ & & $-0.003 * *$ &
\end{tabular}




\begin{tabular}{|c|c|c|c|c|c|c|}
\hline \multirow{2}{*}{ Variable } & \multicolumn{2}{|c|}{ LPM } & \multicolumn{2}{|c|}{ LOGIT } & \multicolumn{2}{|c|}{ PROBIT } \\
\hline & RES (1) & RES (2) & RES (3) & RES (4) & RES (5) & RES (6) \\
\hline & $(0.001)$ & & $(0.003)$ & & $(0.002)$ & \\
\hline \multirow[t]{2}{*}{ CR3 } & & $-0.001 *$ & & $-0.005^{*}$ & & $-0.003^{*}$ \\
\hline & & $(0.001)$ & & $(0.003)$ & & $(0.002)$ \\
\hline \multirow[t]{2}{*}{ FOR } & $0.002 * *$ & $0.002 * *$ & $0.009 *$ & 0.009 & $0.006^{*}$ & $0.006^{*}$ \\
\hline & $(0.001)$ & $(0.001)$ & $(0.006)$ & $(0.006)$ & $(0.003)$ & $(0.003)$ \\
\hline \multirow[t]{2}{*}{ MAN } & 0.001 & 0.001 & 0.007 & 0.006 & 0.003 & 0.003 \\
\hline & $(0.001)$ & $(0.001)$ & $(0.008)$ & $(0.008)$ & $(0.004)$ & $(0.004)$ \\
\hline \multirow[t]{2}{*}{ GOV } & -0.001 & -0.001 & $-0.006^{*}$ & $-0.006^{*}$ & $-0.004 *$ & $-0.004 *$ \\
\hline & $(0.001)$ & $(0.001)$ & $(0.003)$ & $(0.003)$ & $(0.002)$ & $(0.002)$ \\
\hline \multirow[t]{2}{*}{ BOA } & 0.006 & 0.006 & 0.018 & 0.018 & 0.012 & 0.012 \\
\hline & $(0.010)$ & $(0.010)$ & $(0.054)$ & $(0.054)$ & $(0.032)$ & $(0.032)$ \\
\hline \multirow[t]{2}{*}{ OUT } & -0.001 & -0.002 & 0.007 & 0.005 & 0.001 & -0.000 \\
\hline & $(0.011)$ & $(0.011)$ & $(0.063)$ & $(0.063)$ & $(0.037)$ & $(0.037)$ \\
\hline \multirow[t]{2}{*}{ LEV } & $0.580 * * *$ & $0.578 * * *$ & $3.188 * * *$ & $3.180 * * *$ & $1.875^{* * * *}$ & $1.870 * * *$ \\
\hline & $(0.071)$ & $(0.071)$ & $(0.430)$ & $(0.430)$ & $(0.251)$ & $(0.251)$ \\
\hline \multirow[t]{2}{*}{ AGE } & $-0.018 * * *$ & $-0.018 * * *$ & $-0.097 * * *$ & $-0.097 * * *$ & $-0.059 * * *$ & $-0.059 * * *$ \\
\hline & $(0.004)$ & $(0.004)$ & $(0.025)$ & $(0.025)$ & $(0.015)$ & $(0.015)$ \\
\hline \multirow[t]{2}{*}{ CAS } & $0.025 * * *$ & $0.025 * * *$ & $0.136 * * *$ & $0.137 * * *$ & $0.085 * * *$ & $0.085 * * *$ \\
\hline & $(0.008)$ & $(0.008)$ & $(0.046)$ & $(0.046)$ & $(0.027)$ & $(0.027)$ \\
\hline \multirow[t]{2}{*}{ PRO } & 0.018 & 0.018 & 0.101 & 0.101 & 0.064 & 0.064 \\
\hline & $(0.016)$ & $(0.016)$ & $(0.084)$ & $(0.084)$ & $(0.050)$ & $(0.050)$ \\
\hline \multirow[t]{2}{*}{ GRO } & $0.138 * * *$ & $0.138 * * *$ & $0.795 * * *$ & $0.796 * * *$ & $0.454 * * *$ & $0.454 * * *$ \\
\hline & $(0.025)$ & $(0.025)$ & $(0.159)$ & $(0.159)$ & $(0.088)$ & $(0.088)$ \\
\hline \multirow[t]{2}{*}{ _cons } & $-0.326^{*}$ & $-0.332 *$ & $-4.619 * * *$ & $-4.652 * * *$ & $-2.795 * * *$ & $-2.812^{* * *}$ \\
\hline & $(0.183)$ & $(0.183)$ & (1.092) & (1.092) & $(0.643)$ & $(0.643)$ \\
\hline
\end{tabular}




\begin{tabular}{|c|c|c|c|c|c|c|}
\hline \multirow{2}{*}{ Variable } & \multicolumn{2}{|c|}{ LPM } & \multicolumn{2}{|c|}{ LOGIT } & \multicolumn{2}{|c|}{ PROBIT } \\
\hline & RES (1) & RES (2) & RES (3) & RES (4) & RES (5) & RES (6) \\
\hline \multicolumn{7}{|l|}{$\operatorname{lnsig} 2 u$} \\
\hline \multirow[t]{2}{*}{ _cons } & & & $-1.059 * * *$ & $-1.051 * * *$ & $-2.063 * * *$ & $-2.057 * * *$ \\
\hline & & & $(0.397)$ & $(0.395)$ & $(0.381)$ & $(0.380)$ \\
\hline \multirow[t]{2}{*}{ sigma_u } & 0.091 & 0.091 & $0.589 * * *$ & $0.591 * * *$ & $0.356 * * *$ & $0.358 * * *$ \\
\hline & & & $(0.117)$ & $(0.117)$ & $(0.068)$ & $(0.068)$ \\
\hline \multirow[t]{2}{*}{ rho } & 0.044 & 0.044 & $0.095 * * *$ & $0.096 * * *$ & $0.113 * * *$ & $0.113 * * *$ \\
\hline & & & $(0.034)$ & $(0.034)$ & $(0.038)$ & $(0.038)$ \\
\hline$N$ & 1575 & 1575 & 1575 & 1575 & 1575 & 1575 \\
\hline
\end{tabular}

Notes: The corporate performance is measured by Tobin's Q. The restructuring dummy is figured 1 for the restructuring firm and 0 for the non-restructuring firm. The level of restructuring is proxied by difference of firm's asset. Standard error is in parentheses. *, **, and *** denote significance levels of $10 \%, 5 \%$, and $1 \%$, respectively.

Finally, it is found that the effects of firm characteristics on restructuring are remarkable. The coefficients of leverage (LEV) are statistically significant. Noting again that only firms in the rapid development period have LEV greater than $48.32 \%$ (see Table 2), the results indicate that the logit transformation of LEV is positively related to restructuring. It appears that higher debt ratio is risky for finance situation in the long run (Fukui \& Ushijima, 2007; Perry \& Shivdasani, 2005). Moreover, it is asserted that strong performance allows insiders not only to retain control of director boards but also to engage in corporate restructuring. The coefficients of age (AGE) are negatively related to restructuring, which is consistent with the outcomes of previous studies (Jefferson \& Su, 2006; Zhang et al., 2001). Interestingly, the relationships between free cash flow (CAS) and restructuring and between sales growth (GRO) and restructuring are significant and positive in the three estimators. 


\section{Table 4}

Binary models for the effect of Tobin's Q on restructuring

\begin{tabular}{|c|c|c|c|c|c|c|}
\hline \multirow{2}{*}{ Variable } & \multicolumn{2}{|c|}{ LPM } & \multicolumn{2}{|c|}{ LOGIT } & \multicolumn{2}{|c|}{ PROBIT } \\
\hline & RES (1) & RES (2) & RES (3) & RES (4) & RES (5) & RES (6) \\
\hline \multirow[t]{2}{*}{ TOQ } & $0.136^{* * *}$ & $0.136 * * *$ & $0.803 * * *$ & $0.802 * * *$ & $0.460 * * *$ & $0.459 * * *$ \\
\hline & $(0.027)$ & $(0.027)$ & $(0.169)$ & $(0.169)$ & $(0.096)$ & $(0.096)$ \\
\hline \multirow[t]{2}{*}{ OWN } & $-0.001 *$ & & $-0.005^{*}$ & & $-0.003 *$ & \\
\hline & $(0.001)$ & & $(0.003)$ & & $(0.002)$ & \\
\hline \multirow[t]{2}{*}{ CR3 } & & -0.001 & & -0.005 & & -0.003 \\
\hline & & $(0.001)$ & & $(0.003)$ & & $(0.002)$ \\
\hline \multirow[t]{2}{*}{ FOR } & $0.002 * *$ & $0.002 *$ & 0.009 & 0.008 & $0.005^{*}$ & 0.005 \\
\hline & $(0.001)$ & $(0.001)$ & $(0.006)$ & $(0.006)$ & $(0.003)$ & $(0.003)$ \\
\hline \multirow[t]{2}{*}{ MAN } & 0.001 & 0.001 & 0.003 & 0.003 & 0.001 & 0.001 \\
\hline & $(0.001)$ & $(0.001)$ & $(0.008)$ & $(0.008)$ & (0.004) & $(0.004)$ \\
\hline \multirow[t]{2}{*}{ GOV } & -0.001 & -0.001 & -0.005 & -0.005 & -0.003 & -0.003 \\
\hline & $(0.001)$ & $(0.001)$ & $(0.003)$ & $(0.003)$ & $(0.002)$ & $(0.002)$ \\
\hline \multirow[t]{2}{*}{ BOA } & 0.000 & 0.000 & -0.007 & -0.007 & -0.003 & -0.003 \\
\hline & $(0.010)$ & $(0.010)$ & $(0.053)$ & $(0.053)$ & $(0.032)$ & $(0.032)$ \\
\hline \multirow[t]{2}{*}{ OUT } & -0.004 & -0.004 & -0.016 & -0.018 & -0.010 & -0.011 \\
\hline & $(0.012)$ & $(0.012)$ & $(0.061)$ & $(0.061)$ & $(0.037)$ & $(0.037)$ \\
\hline \multirow[t]{2}{*}{ LEV } & $0.304 * * *$ & $0.303 * * *$ & $1.502 * * *$ & $1.496 * * *$ & $0.917 * * *$ & $0.913 * * *$ \\
\hline & $(0.064)$ & $(0.064)$ & $(0.353)$ & $(0.353)$ & $(0.209)$ & $(0.209)$ \\
\hline \multirow[t]{2}{*}{ AGE } & $-0.026 * * *$ & $-0.026 * * *$ & $-0.135 * * *$ & $-0.135 * * *$ & $-0.082 * * *$ & $-0.082 * * *$ \\
\hline & (0.004) & $(0.004)$ & $(0.024)$ & $(0.024)$ & $(0.014)$ & $(0.014)$ \\
\hline \multirow[t]{2}{*}{ CAS } & $0.035 * * *$ & $0.036 * * *$ & $0.191 * * *$ & $0.192 * * *$ & $0.117 * * *$ & $0.117 * * *$ \\
\hline & (0.008) & $(0.008)$ & $(0.045)$ & $(0.045)$ & $(0.027)$ & $(0.027)$ \\
\hline PRO & 0.026 & 0.025 & 0.131 & 0.131 & 0.081 & 0.081 \\
\hline
\end{tabular}




\begin{tabular}{|c|c|c|c|c|c|c|}
\hline \multirow{2}{*}{ Variable } & \multicolumn{2}{|c|}{ LPM } & \multicolumn{2}{|c|}{ LOGIT } & \multicolumn{2}{|c|}{ PROBIT } \\
\hline & RES (1) & RES (2) & RES (3) & RES (4) & RES (5) & RES (6) \\
\hline & $(0.016)$ & $(0.016)$ & $(0.084)$ & $(0.084)$ & $(0.050)$ & $(0.050)$ \\
\hline \multirow[t]{2}{*}{ GRO } & $0.169 * * *$ & $0.169 * * *$ & $1.037 * * *$ & $1.038 * * *$ & $0.577 * * *$ & $0.577 * * *$ \\
\hline & $(0.025)$ & $(0.025)$ & $(0.160)$ & $(0.160)$ & $(0.087)$ & $(0.087)$ \\
\hline \multirow[t]{2}{*}{ _cons } & $-0.422 * *$ & $-0.426 * *$ & $-5.004 * * *$ & $-5.032 * * *$ & $-3.020 * * *$ & $-3.036 * * *$ \\
\hline & $(0.185)$ & $(0.185)$ & (1.083) & (1.083) & $(0.637)$ & $(0.638)$ \\
\hline \multicolumn{7}{|l|}{$\operatorname{lnsig} 2 u$} \\
\hline \multirow[t]{2}{*}{ _cons } & & & $-1.118 * * *$ & $-1.112 * * *$ & $-2.142 * * *$ & $-2.136 * * *$ \\
\hline & & & $(0.394)$ & (0.393) & $(0.390)$ & $(0.388)$ \\
\hline \multirow[t]{2}{*}{ sigma_u } & 0.431 & 0.431 & $0.571 * * *$ & $0.573 * * *$ & $0.343 * * *$ & $0.344 * * *$ \\
\hline & & & $(0.113)$ & $(0.112)$ & $(0.068)$ & $(0.067)$ \\
\hline \multirow[t]{2}{*}{ rho } & 0.043 & 0.043 & $0.090 * * *$ & $0.091 * * *$ & $0.105 * * *$ & $0.106^{* * *}$ \\
\hline & & & $(0.032)$ & $(0.032)$ & $(0.037)$ & $(0.037)$ \\
\hline$N$ & 1575 & 1575 & 1575 & 1575 & 1575 & 1575 \\
\hline
\end{tabular}

Notes: The corporate performance is measured by Tobin's Q. The restructuring dummy is figured 1 for the restructuring firm and 0 for the non-restructuring firm. The level of restructuring is proxied by difference of firm's asset. Standard error is in parentheses. *, **, and *** denote significance levels of $10 \%, 5 \%$, and $1 \%$, respectively.

In general, the above empirical results support the hypothesis that performance, ownership structure, and firm characteristics are major determinants of corporate restructuring. This is consistent with the findings of Perry and Shivdasani (2005) that corporate structuring is a response to performance in the manner in harmony with value maximization.

\subsection{Effects of corporate restructuring on performance}

In this part we consider whether corporate restructuring improves corporate performance. Eq. 2 is estimated by the system-GMM method, by which firm performance is measured by ROA, Tobin's Q, restructuring level, percentage of change in assets (DAS), board size, the number of all executive and non-executive directors, board independence, and the number of outside directors in the board. We conduct 
estimations by performing them separately for restructuring companies (percentage of change in assets more than or equal to 5\%) and non-restructuring companies (percentage of change in assets less than 5\%). Table 5 presents the estimated results from Eq. 2. Some main findings are interesting. Board size and board independence have positive and significant effects on TOQ and ROA, which is in line with the study of Morck et al. (1988) and implies that corporate restructuring in Vietnam during the 2007-2014 period is characterized by reduction in ownership concentration and improvement in corporate governance. The argument supports the hypothesis that corporate restructuring has greater impact on firm performance as measured by Tobin's Q.

Regarding other control variables, the effect of firm life (AGE) on corporate performance is negative and statically significant. It implies that mature firms tend to grow at lower rates and achieve lower levels of performance. The variable LEV has a negative and significant impact on corporate performance, implying that a higher leverage could increase the volatility of earnings. The variable OUT has a positive and significant effect on performance of the firm, which is measured by Tobin's Q. This suggests that outside directors effectively act as a monitoring device and whistle-blower. As a result, they help firm boards make better decisions. Moreover, the statistically significant and larger effect of outside directors on the market-based measure of firm performance indicates the forward-looking valuation perception of investors. This outcome is consistent with that of previous studies (Dahya \& McConnell, 2007).

The rationality of the instruments used in GMM is assessed through Sargan and Arellano-Bond test statistics. The p-value of Sargan statistics should be as large as possible. For another, Arellano-Bond test is used to check the autocorrelation of errors in the form of first difference. The p-value of Sargan and Arellano-Bond statistics is statistically significant in most models, which confirms that instrumental variables used in GMM estimators are exogenous and have no correlation with residuals, and that the variables in these models do not have autocorrelation.

\subsection{Robustness checks}

We check the robustness of performance-enhancing impacts of restructuring by performing three-stage least squares (3SLS) and seemingly unrelated regression (SUR) estimations. In Eq. 2 we use the dependent variable DAS to replace RES (dummy variable). As shown in Table 6 the empirical results are consistent with those of GMM estimator. ROA and TOQ have positive and significant effects on corporate 
restructuring. The effects of other control variables estimated by 3SLS and SUR estimators are highly consistent with GMM estimations, and several similar and interesting findings are revealed. First, mature firms find it difficult to maintain a high rate of growth and face a decline in their performance. Second, a high level of debt usage also causes a reduction in firm performance because high leverage is accompanied by a larger volatility of earnings. Third, apart from foreign ownership, which exerts a positive impact on the restructuring process, a larger holding by dominant shareholders, such as governments and managers, has negative and statistically significant effects (see Table 6). The negative influence of dominant shareholders on restructuring of the firm is consistent with the existing literature (Dahya et al., 2008; Munisi et al., 2014). We suppose that dominant shareholders have incentive to divert firm resources from small shareholders in order to finance their personal consumptions, especially in the country where shareholders are not well protected by laws and regulations. Therefore, dominant shareholders cause a rise in agency costs, which then reduce the firm's market value.

\section{Table 5}

Determinants of corporate performance

\begin{tabular}{|c|c|c|c|c|c|c|c|c|}
\hline & 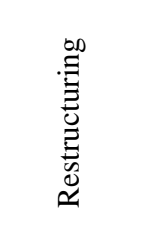 & 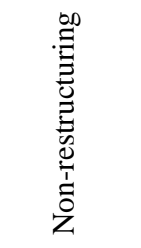 & 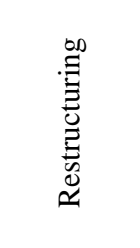 & 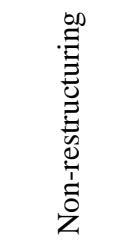 & 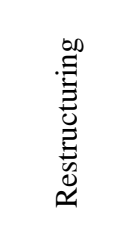 & 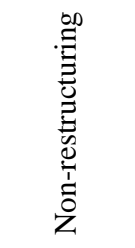 & 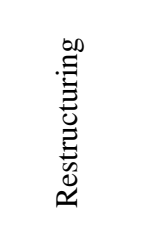 & 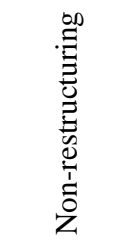 \\
\hline & (1) & (2) & (3) & (4) & $(5)$ & (6) & (7) & (8) \\
\hline & ROA & ROA & ROA & ROA & TOQ & TOQ & TOQ & TOQ \\
\hline \multirow[t]{2}{*}{ CR3 } & $0.000 * * *$ & $0.000 * * *$ & $0.000 * * *$ & $0.000 * * *$ & 0.001 & $0.002 * * *$ & 0.001 & $0.001 * *$ \\
\hline & $(0.000)$ & $(0.000)$ & $(0.000)$ & $(0.000)$ & $(0.001)$ & $(0.000)$ & $(0.001)$ & $(0.001)$ \\
\hline \multirow[t]{2}{*}{ BOA } & $0.012 * * *$ & $0.010 * *$ & & & $0.232 * * *$ & $0.102 * * *$ & & \\
\hline & $(0.002)$ & $(0.004)$ & & & $(0.022)$ & $(0.017)$ & & \\
\hline \multirow[t]{2}{*}{ OUT } & & & $0.010 * * *$ & 0.007 & & & $0.263 * * *$ & $0.176 * * *$ \\
\hline & & & $(0.003)$ & $(0.006)$ & & & $(0.029)$ & $(0.028)$ \\
\hline \multirow[t]{2}{*}{ DAS } & 0.005 & $0.085 * * *$ & -0.004 & $0.083 * * *$ & $0.387 * * *$ & $0.159 * *$ & 0.161 & 0.069 \\
\hline & (0.014) & (0.019) & $(0.015)$ & $(0.020)$ & $(0.130)$ & $(0.077)$ & $(0.130)$ & $(0.090)$ \\
\hline
\end{tabular}




\begin{tabular}{|c|c|c|c|c|c|c|c|c|}
\hline & 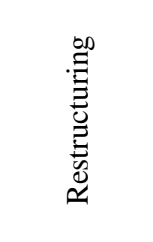 & 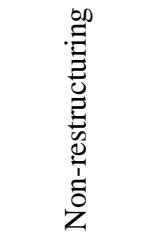 & 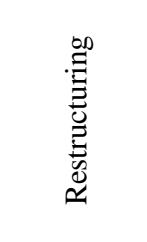 & 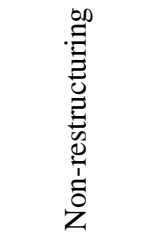 & 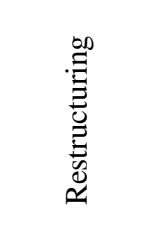 & 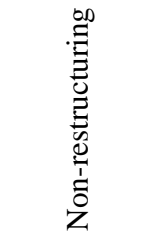 & 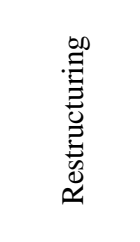 & 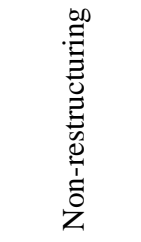 \\
\hline & (1) & (2) & (3) & (4) & (5) & (6) & (7) & (8) \\
\hline & ROA & ROA & ROA & ROA & TOQ & TOQ & TOQ & TOQ \\
\hline \multirow[t]{2}{*}{ LEV } & $-0.249 * * *$ & $-0.220 * * *$ & $-0.244 * * *$ & $-0.218 * * *$ & $-0.313 * * *$ & $0.088^{*}$ & $-0.160 * *$ & $0.214 * * *$ \\
\hline & $(0.009)$ & $(0.011)$ & $(0.009)$ & $(0.012)$ & $(0.079)$ & $(0.046)$ & $(0.079)$ & $(0.054)$ \\
\hline \multirow[t]{2}{*}{ AGE } & $-0.006 * * *$ & $-0.007 * * *$ & $-0.006^{* * *}$ & $-0.007 * * *$ & $-0.016^{* *}$ & $-0.014 * * *$ & -0.008 & $-0.021 * * *$ \\
\hline & $(0.001)$ & $(0.001)$ & $(0.001)$ & $(0.001)$ & $(0.007)$ & $(0.004)$ & $(0.007)$ & $(0.005)$ \\
\hline \multirow[t]{2}{*}{ _cons } & $0.175^{* * *}$ & $0.124 * * *$ & $0.200 * * *$ & $0.149 * * *$ & -0.070 & $0.298 * * *$ & $0.255^{* * *}$ & $0.255^{* * *}$ \\
\hline & $(0.012)$ & $(0.020)$ & $(0.010)$ & $(0.020)$ & $(0.108)$ & $(0.081)$ & $(0.089)$ & $(0.086)$ \\
\hline$N$ & 987 & 592 & 987 & 592 & 987 & 592 & 987 & 592 \\
\hline $\begin{array}{l}\text { Sargan } \\
\text { test }\end{array}$ & 0.088 & 0.574 & 0.106 & 0.371 & 0.040 & 0.490 & 0.001 & 0.270 \\
\hline $\mathrm{AR}(2)$ & 0.084 & 0.740 & 0.080 & 0.842 & 0.618 & 0.921 & 0.070 & 0.653 \\
\hline
\end{tabular}

Notes: The corporate performance is measured by ROA and Tobin's Q. The level of restructuring is proxied by the difference of firm's asset. The board compostion is measured by board size and the number of outside directors. The endogenous variables are board structure indicators. In addition, the coverage of corporate characteristic, such as leverage, firm age, free flow cash, profit margin, and sales growth, is significant due to additional restrictions imposed by the availability of exogenous instruments and the use of lagged variables as instruments.

This table presents a comparisons of performance changes for companies that underwent restructuring versus those that did not. We use the Kruskal-Wallis test for the differences between restructuring and non-restructuring firms. Krusual-Wallis test statistic uses the ' $p$ ' value involving the chi-square approximation. Standard error is in parentheses. *,**, and *** denote significance levels of $10 \%$, $5 \%$, and $1 \%$, respectively.

\section{Table 6}

Simultaneous equations estimates for corporate restructuring and performance

\begin{tabular}{lllllll}
\hline & \multicolumn{2}{c}{3 SLS } & \multicolumn{2}{c}{ SUR } & \multicolumn{2}{c}{ BI-PROBIT } \\
\cline { 2 - 6 } & RES (1) & RES (2) & RES (3) & RES (4) & RES (5) & RES (6) \\
\hline ROA & $9.860^{* * *}$ & & $1.869 * * *$ & & $4.091 * * *$ &
\end{tabular}




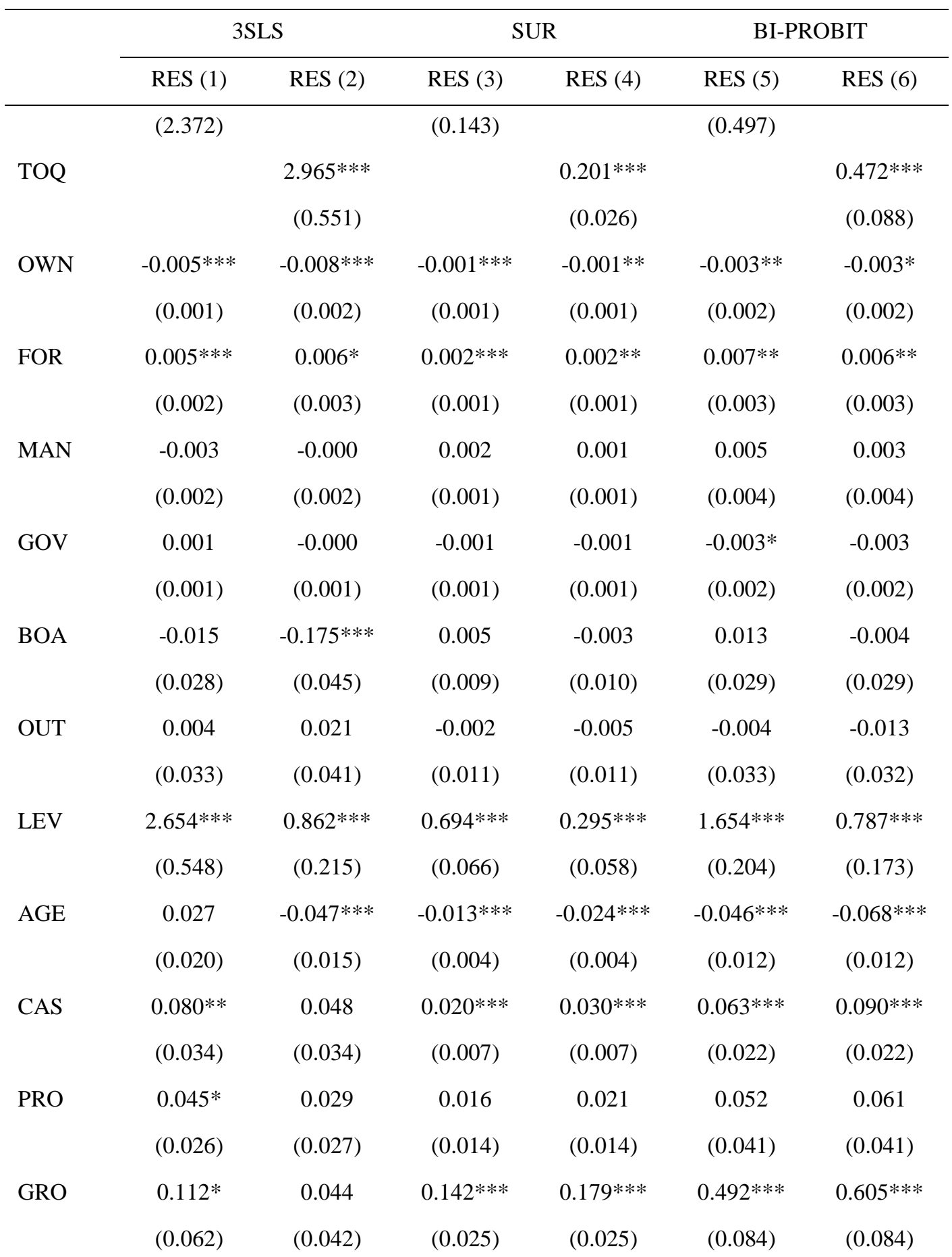




\begin{tabular}{|c|c|c|c|c|c|c|}
\hline & \multicolumn{2}{|c|}{$3 S L S$} & \multicolumn{2}{|c|}{ SUR } & \multicolumn{2}{|c|}{ BI-PROBIT } \\
\hline & RES (1) & RES (2) & RES (3) & RES (4) & RES (5) & RES (6) \\
\hline \multirow[t]{3}{*}{ _cons } & $-3.398 * * *$ & $-2.694 * * *$ & $-0.319 *$ & $-0.339 * *$ & $-2.204 * * *$ & $-2.410 * * *$ \\
\hline & $(0.411)$ & $(0.495)$ & $(0.169)$ & $(0.172)$ & $(0.522)$ & $(0.520)$ \\
\hline & $\mathrm{ROA}$ & TOQ & $\mathrm{ROA}$ & TOQ & $\mathrm{ROA}$ & ROA \\
\hline \multirow[t]{2}{*}{ CR3 } & $0.000 * * *$ & $0.003 * * *$ & $0.000 * * *$ & $0.003 * * *$ & $-0.062 *$ & $-0.063 *$ \\
\hline & $(0.000)$ & $(0.000)$ & $(0.000)$ & $(0.000)$ & $(0.036)$ & $(0.037)$ \\
\hline \multirow[t]{2}{*}{ BOA } & 0.002 & $0.061 * * *$ & 0.002 & $0.061 * * *$ & $0.562 *$ & $0.559 *$ \\
\hline & $(0.002)$ & $(0.009)$ & $(0.002)$ & $(0.009)$ & $(0.297)$ & $(0.294)$ \\
\hline \multirow[t]{2}{*}{ OUT } & -0.002 & -0.012 & -0.003 & -0.012 & 0.393 & 0.405 \\
\hline & $(0.002)$ & $(0.011)$ & $(0.002)$ & $(0.011)$ & $(0.330)$ & $(0.332)$ \\
\hline \multirow[t]{2}{*}{ DAS } & $0.081 * * *$ & $0.271 * * *$ & $0.095 * * *$ & $0.254 * * *$ & 1.038 & 0.800 \\
\hline & $(0.008)$ & $(0.022)$ & $(0.008)$ & $(0.043)$ & $(1.450)$ & $(1.545)$ \\
\hline \multirow[t]{2}{*}{ LEV } & $-0.244 * * *$ & $-0.210 * * *$ & $-0.245 * * *$ & $-0.208 * * *$ & -3.232 & -3.159 \\
\hline & $(0.010)$ & $(0.056)$ & $(0.010)$ & $(0.056)$ & $(2.514)$ & $(2.529)$ \\
\hline \multirow[t]{2}{*}{ AGE } & $-0.004 * * *$ & $0.010 * *$ & $-0.004 * * *$ & $0.009 * *$ & 0.156 & 0.145 \\
\hline & $(0.001)$ & $(0.004)$ & $(0.001)$ & $(0.004)$ & $(0.148)$ & $(0.145)$ \\
\hline \multirow[t]{2}{*}{ _cons } & $0.190 * * *$ & $0.655 * * *$ & $0.187 * * *$ & $0.652 * * *$ & $10.854 * *$ & $10.864 * *$ \\
\hline & $(0.009)$ & $(0.050)$ & $(0.009)$ & $(0.050)$ & $(4.278)$ & $(4.297)$ \\
\hline \multicolumn{7}{|l|}{ athrho } \\
\hline \multirow[t]{2}{*}{ _cons } & & & & & 0.035 & 0.166 \\
\hline & & & & & $(0.479)$ & $(0.489)$ \\
\hline$N$ & 1575 & 1575 & 1575 & 1575 & 1575 & 1575 \\
\hline
\end{tabular}

Notes: The corporate performance is measured by ROA and Tobin's Q. The board independence is measured by the proportion of shares owned by shareholders who own at least $5 \%$ of all shares outstanding at year end and the ratio of shares owned by three largest shareholders to total shares. Standard error is in parentheses. *,**, and *** denote significance levels of $10 \%, 5 \%$, and $1 \%$, respectively. 


\section{Concluding remarks}

In the context of integration into the ASEAN Economic Community (AEC) and participation in Trans-Pacific Partnership (TPP) Agreement, Vietnamese businesses are confronting with challenges in corporate governance and administration, such as lack of strategies, cash flow imbalances, human resource shortfalls, and improper operating systems. Moreover, the biggest restructuring pressure lies in economic recession and financial crisis, in which they encounter a sharp decline in consumer demand. Vietnamese businesses must accelerate their restructuring strategies as a response to radical changes in business environment caused by regional and international integration and changes in various laws. This paper contributes a novel perspective concerning corporate restructuring in Vietnam, which measured by asset restructuring in the theoretical framework of corporate portfolio restructuring. This point of view is entirely consistent as compared to global trends and modern theoretical framework concerning restructuring: portfolio, financial, and organizational. Most critics of Vietnamese corporate restructuring merely focus on ownership analyses; however, there has been a misleading concept about what is meant by corporate restructuring. The analytical framework of this study offers overwhelmingly greater reliability relying on the agency theory to explain restructuring activities (Bowman \& Singh, 1993; Denis \& Kruse, 2000). The two core aims of this paper are to investigate: (i) the determinants of corporate restructuring in Vietnam; and (ii) the effects of corporate restructuring on performance. A series of main variables employed in this study has also been considered carefully. The level of corporate restructuring is measured by percentage of change in the firm's asset, whereas ROA and Tobin's Q ratios are used as proxies for performance. The empirical results suggest several intriguing findings as follows:

First, corporate performance has a positive effect whether the firm carries out restructuring. A few existing studies intensively measure the impact of performance change on restructuring (Denis \& Kruse, 2000; Perry \& Shivdasani, 2005); nevertheless, the results are entirely unclear. We suggest that the decision of restructuring made by an enterprise should primarily depend on its performance. Ownership structure also has impacts on the process of restructuring. Specifically, foreign holdings lead to an increase in restructuring activities, whereas domestic holdings (only government) cause a decline in such a claim. The reason may be such that foreign investors, either individuals or 
institutions, have better managerial skills and provide essential warnings for a weak board and corporate portfolio structure.

Second, we have focused attention on the difficult question of whether corporate restructuring affects performance. Our principle is to measure the effect of restructuring on performance of restructuring and non-restructuring enterprises. If most factors of performance, ownership structure, and firm's board and characteristics are a source of restructuring activities, then post-restructuring performance should necessarily be expected to improve, especially compared to a firm in the pre-restructuring or nonrestructuring period. It is shown that board composition with the presence of outside directors has a positive and statistically significant impact on firm performance, which implies that directors from outside the firm play a crucial role in preventing the misconduct of firm management.

Third, firm-specific characteristics exert effects as expected on corporate performance. In Vietnam, the use of financial leverage may increase the variation of a firm's earning, which reduces its performance. The results also indicate that mature firms face a decrease in their performance.

Last, firms in Vietnam have opportunities to enjoy the economic scales since the effect of asset restructuring on performance is positive and significant.

The critical implication that can be drawn from the above findings is that Vietnam's corporate restructuring in the coming years should take account of ownership structure changes, especially foreign holdings. This change can bring new styles of leadership and support changes in business operations and business strategies. Based on changes in ownership structure, Vietnamese companies will make alterations to corporate culture and management mechanisms — such as the way bonuses are awarded - in order to encourage employees' potential. Spiritual encouragement, mutual understanding, and sympathy with employees are the key to unlock their potentials

\section{References}

Anderson, G. J. (1987). Prediction tests in limited dependent variable models. Journal of Econometrics, 34(1), 253-261.

Arellano, M., \& Bond, S. (1991). Some tests of specification for panel data: Monte Carlo evidence and an application to employment equations. The Review of Economic Studies, 58(2), 277-297. 
Arellano, M., \& Bover, O. (1995). Another look at the instrumental variable estimation of errorcomponents models. Journal of Econometrics, 68(1), 29-51.

Baek, J.-S., Kang, J.-K., \& Park, K. S. (2004). Corporate governance and firm value: Evidence from the Korean financial crisis. Journal of Financial Economics, 71(2), 265-313.

Baum, C. F., Schaffer, M. E., \& Stillman, S. (2003). Instrumental variables and GMM: Estimation and testing. Stata Journal, 3(1), 1-31.

Bergh, D. D. (1998). Product-market uncertainty, portfolio restructuring, and performance: An information-processing and resource-based view. Journal of Management, 24(2), 135-155.

Bethel, J. E., \& Liebeskind, J. (1993). The effects of ownership structure on corporate restructuring. Strategic Management Journal, 14(S1), 15-31.

Bhagat, S., \& Black, B. (1999). The uncertain relationship between board composition and firm performance. The Business Lawyer, 54(3), 921-963.

Bleackley, M., \& Williamson, P. (1997). The nature and extent of corporate restructuring within Europe's single market: Cutting through the hype. European Management Journal, 15(5), 484 497.

Blundell, R., \& Bond, S. (1998). Initial conditions and moment restrictions in dynamic panel data models. Journal of Econometrics, 87(1), 115-143.

Blundell, R., \& Bond, S. (2000). GMM estimation with persistent panel data: An application to production functions. Econometric Reviews, 19(3), 321-340.

Blundell, R., Bond, S., \& Windmeijer, F. (2000). Estimation in dynamic panel data models: Improving on the performance of the standard GMM estimator. Advances in Econometrics. JAI Press, Elsevier Science, Amsterdam, 15.

Bowman, E. H., \& Singh, H. (1993). Corporate restructuring: Reconfiguring the firm. Strategic Management Journal (1986-1998), 14(Special Issue), 5.

Brauer, M., \& Laamanen, T. (2014). Workforce downsizing and firm performance: An organizational routine perspective. Journal of Management Studies, 51(8), 1311-1333.

Brush, T. H., Bromiley, P., \& Hendrickx, M. (2000). The free cash flow hypothesis for sales growth and firm performance. Strategic Management Journal, 21(4), 455-472.

Büchelhofer, C. (2008). Corporate control and enterprise reform in China: An econometric analysis of block share trades. Berlin, Germany: Springer.

Carter, D. A., Simkins, B. J., \& Simpson, W. G. (2003). Corporate governance, board diversity, and firm value. Financial Review, 38(1), 33-53.

Champlin, D. P., \& Knoedler, J. T. (1999). Restructuring by design: Government's complicity in corporate restructuring. Journal of Economic Issues, 33(1), 41-57.

Chen, C. H., \& Al-Najjar, B. (2012). The determinants of board size and independence: Evidence from China. International Business Review, 21(5), 831-846. 
Chen, C.-J., \& Yu, C.-M. J. (2012). Managerial ownership, diversification, and firm performance: Evidence from an emerging market. International Business Review, 21(3), 518-534.

Cho, D. S., \& Kim, J. (2007). Outside directors, ownership structure, and firm profitability in Korea. Corporate Governance: An International Review, 15(2), 239-250.

Claessens, S., Djankov, S., Fan, J. P., \& Lang, L. H. (2003). When does corporate diversification matter to productivity and performance? Evidence from East Asia. Pacific-Basin Finance Journal, $11(3), 365-392$.

Claessens, S., Djankov, S., \& Lang, L. H. P. (2000). The separation of ownership and control in East Asian corporations. Journal of Financial Economics, 58(1-2), 81-112.

Coles, J. L., Daniel, N. D., \& Naveen, L. (2008). Boards: Does one size fit all? Journal of Financial Economics, 87(2), 329-356.

Comment, R., \& Jarrell, G. A. (1995). Corporate focus and stock returns. Journal of Financial Economics, 37(1), 67-87.

Dahya, J., \& McConnell, J. J. (2007). Board composition, corporate performance, and the Cadbury committee recommendation. Journal of Financial and Quantitative Analysis, 42(3), 535-564.

Dahya, J., McConnell, J. J., \& Dimitrov, O. (2008). Dominant shareholders, corporate boards, and corporate value: A cross-country analysis. Journal of Financial Economics, 87(1), 73-100.

De Meuse, K. P., Bergmann, T. J., Vanderheiden, P. A., \& Roraff, C. E. (2004). New evidence regarding organizational downsizing and a firm's financial performance: A long-term analysis. Journal of Managerial Issues, 16(2), 155-177.

Denis, D. J., Denis, D. K., \& Sarin, A. (1997). Agency problems, equity ownership, and corporate diversification. Journal of Finance, 52(1), 135-160.

Denis, D. J., \& Kruse, T. A. (2000). Managerial discipline and corporate restructuring following performance declines. Journal of Financial Economics, 55(3), 391-424.

Dharwadkar, B., George, G., \& Brandes, P. (2000). Privatization in emerging economies: An agency theory perspective. Academy of Management Review, 25(3), 650-669.

Dittmar, A., \& Shivdasani, A. (2003). Divestitures and divisional investment policies. The Journal of Finance, 58(6), 2711-2744.

D'Souza, J., Megginson, W., \& Nash, R. (2005). Effect of institutional and firm-specific characteristics on post-privatization performance: Evidence from developed countries. Journal of Corporate Finance, 11(5), 747-766.

D'Souza, J., Megginson, W., \& Nash, R. (2007). The effects of changes in corporate governance and restructurings on operating performance: Evidence from privatizations. Global Finance Journal, $18(2), 157-184$.

Fama, E. F., \& Jensen, M. (1983). Separation of ownership and control. Journal of Law and Economics, 26(2), 301-326. 
Fukui, Y., \& Ushijima, T. (2007). Corporate diversification, performance, and restructuring in the largest Japanese manufacturers. Journal of the Japanese and International Economies, 21(3), 303-323.

Ghosh, C., \& Sirmans, C. (2003). Board independence, ownership structure, and performance: Evidence from real estate investment trusts. The Journal of Real Estate Finance and Economics, 26(2-3), 287-318.

Gibbs, P. A. (1993). Determinants of corporate restructuring: The relative importance of corporate governance, takeover threat, and free cash flow. Strategic Management Journal, 14(S1), 51- 68.

GSO. (2013). Statistical Yearbook 2013. Hanoi, Vietnam: General Statistics Office Of Vietnam.

Guest, P. M. (2008). The determinants of board size and composition: Evidence from the UK. Journal of Corporate Finance, 14(1), 51-72.

Hansen, G. S., \& Hill, C. W. (1991). Are institutional investors myopic? A time-series study of four technology-driven industries. Strategic Management Journal, 12(1), 1-16.

Harris, M., \& Raviv, A. (1988). Corporate control contests and capital structure. Journal of Financial Economics, 20, 55-86.

Harris, M., \& Raviv, A. (1990). Capital structure and the informational role of debt. The Journal of Finance, 45(2), 321-349.

Hermalin, B. E., \& Weisbach, M. S. (1988). The determinants of board composition. RAND Journal of Economics, 19(4), 589-606.

Hillman, A. J., Cannella, A. A., \& Paetzold, R. L. (2000). The resource dependence role of corporate directors: Strategic adaptation of board composition in response to environmental change. Journal of Management Studies, 37(2), 235-256.

Hoskisson, R. E., \& Hitt, M. A. (1990). Antecedents and performance outcomes of diversification: A review and critique of theoretical perspectives. Journal of Management, 16(2), 461-509.

Hoskisson, R. E., \& Turk, T. A. (1990). Corporate restructuring: Governance and control limits of the internal capital market. Academy of Management Review, 15(3), 459-477.

Jackling, B., \& Johl, S. (2009). Board structure and firm performance: Evidence from India's top companies. Corporate Governance: An International Review, 17(4), 492-509.

JBIC. (2003). Soft infrastructure development for better financial access of small and medium enterprises in Vietnam. Tokyo, Japan: Japan Bank for International Cooperation.

Jefferson, G. H., \& Su, J. (2006). Privatization and restructuring in China: Evidence from shareholding ownership, 1995-2001. Journal of Comparative Economics, 34(1), 146-166.

Jensen, M. C. (1986). Agency cost of free cash flow, corporate finance, and takeovers. The American Economic Review, 76(2), 323-329.

Jensen, M. C., \& Meckling, W. H. (1976). Theory of the firm: Managerial behavior, agency costs and ownership structure. Journal of Financial Economics, 3(4), 305-360. 
John, K., Lang, L. H., \& Netter, J. (1992). The voluntary restructuring of large firms in response to performance decline. The Journal of Finance, 47(3), 891-917.

Johnson, R. A., Hoskisson, R. E., \& Hitt, M. A. (1993). Board of director involvement in restructuring: The effects of board versus managerial controls and characteristics. Strategic Management Journal, 14(S1), 33-50.

Kang, J.-K., \& Shivdasani, A. (1997). Corporate restructuring during performance declines in Japan. Journal of Financial Economics, 46(1), 29-65.

Lai, J., \& Sudarsanam, S. (1997). Corporate restructuring in response to performance decline: Impact of ownership, governance, and lenders. European Finance Review, 1(2), 197-233.

Lang, L. H., Stulz, R., \& Walkling, R. A. (1991). A test of the free cash flow hypothesis: The case of bidder returns. Journal of Financial Economics, 29(2), 315-335.

Lasfer, M. A. (2006). The interrelationship between managerial ownership and board structure. Journal of Business Finance \& Accounting, 33(7-8), 1006-1033.

Lee, D., \& Madhavan, R. (2010). Divestiture and firm performance: A meta-analysis. Journal of Management, 36(6), 1345-1371.

Lee, G., \& Teo, A. (2005). Organizational restructuring: Impact on trust and work satisfaction. Asia Pacific Journal of Management, 22(1), 23-39.

Liebeskind, J. P., Opler, T. C., \& Hatfield, D. E. (1996). Corporate restructuring and the consolidation of US industry. The Journal of Industrial Economics, 44(1), 53-68.

Linck, J. S., Netter, J. M., \& Yang, T. (2008). The determinants of board structure. Journal of Financial Economics, 87(2), 308-328.

Lindenberg, E. B., \& Ross, S. A. (1981). Tobin's q ratio and industrial organization. Journal of Business, 54(1), 1-32.

Mak, Y. T., \& Li, Y. (2001). Determinants of corporate ownership and board structure: Evidence from Singapore. Journal of Corporate Finance, 7(3), 235-256.

Markides, C. C. (1992). Consequences of corporate refocusing: Ex ante evidence. Academy of Management Journal, 35(2), 398-412.

McConnell, J. J., \& Servaes, H. (1990). Additional evidence on equity ownership and corporate value. Journal of Financial Economics, 27(2), 595-612.

Morck, R., Shleifer, A., \& Vishny, R. W. (1988). Management ownership and market valuation: An empirical analysis. Journal of Financial Economics, 20, 293-315.

Munisi, G., Hermes, N., \& Randøy, T. (2014). Corporate boards and ownership structure: Evidence from Sub-Saharan Africa. International Business Review, 23(4), 785-796.

Nicholson, G. J., \& Kiel, G. C. (2007). Can directors impact performance? A case-based test of three theories of corporate governance. Corporate Governance: An International Review, 15(4), 585608. 
Nor, F. M., Alias, N., \& Yaacob, M. H. (2008). Corporate restructuring: Film characteristics and performance. Jurnal Pengurusan, 27, 129-141.

Ofek, E. (1993). Capital structure and firm response to poor performance: An empirical analysis. Journal of Financial Economics, 34(1), 3-30.

Pandey, I., \& Ongpipattanakul, V. (2015). Agency behavior and corporate restructuring choices during performance decline in an emerging economy. International Journal of Managerial Finance, 11(2), 244-267.

Park, C., \& Kim, S. (2008). Corporate governance, regulatory changes, and corporate restructuring in Korea, 1993-2004. Journal of World Business, 43(1), 66-84.

Paul, D. L. (2007). Board composition and corrective action: Evidence from corporate responses to bad acquisition bids. Journal of Financial and Quantitative Analysis, 42(3), 759-783.

Perry, T., \& Shivdasani, A. (2005). Do boards affect performance? Evidence from corporate restructuring. The Journal of Business, 78(4), 1403-1432.

Phung, D. N., \& Hoang, T. P. T. (2013). Corporate ownership and firm performance in emerging market: A study of Vietnamese listed firms. Paper presented at the World Business and Social Science Research Conference, Bangkok October.

Pound, J. (1991). Beyond takeovers: Politics comes to corporate control. Harvard Business Review, 70(2), 83-93.

Roodman, D. (2009). How to do xtabond2: An introduction to difference and system GMM in Stata. The Stata Journal, 9(1), 86-136.

Shan, Y. G., \& McIver, R. P. (2011). Corporate governance mechanisms and financial performance in China: Panel data evidence on listed non financial companies. Asia Pacific Business Review, 17(3), 301-324.

Shleifer, A., \& Vishny, R. W. (1986). Large shareholders and corporate control. The Journal of Political Economy, 94(3), 461-488.

Soto, M. (2009). System GMM estimation with a small sample (Barcelona Economics Working Paper Series, No. 395). Barcelona, Spain: Institute for Economic Analysis.

Stinchcombe, A. L., \& March, J. (1965). Social structure and organizations. Advances in Strategic Management, 17, 229-259.

Sun, M. (2012). Impact of divestiture activities on corporate performance: Evidence from listed firms in Taiwan. The International Journal of Business and Finance Research, 6(2), 59-67.

Tran, N. M., Nonneman, W., \& Jorissen, A. (2014). Government ownership and firm performance: The case of Vietnam. International Journal of Economics and Financial Issues, 4(3), 628-650.

Tran, T. C., Le, X. S., \& Nguyen, K. A. (2007). Vietnam's small- and medium-sized enterprises development: Characteristics, constraints, and policy recommendations. In Lim, H. (ed.). SME in 
Asia and globalizatio., ERIA Research Project Report, 2007-5. Jakarta, Indonesia: Economic Research Institute for ASEAN and East Asia (ERIA).

Van den Berghe, L. A., \& Levrau, A. (2004). Evaluating boards of directors: What constitutes a good corporate board? Corporate Governance: An International Review, 12(4), 461-478.

Vo, T. Q., Swierczek, F. W., \& Nguyen, D. K. (2013). Corporate performance of privatized firms in Vietnam. Journal of Applied Business Research, 29(5), 1437-1450.

Yeh, Y.-H., \& Woidtke, T. (2005). Commitment or entrenchment? Controlling shareholders and board composition. Journal of Banking and Finance, 29(7), 1857-1885.

Zajac, E. J., \& Kraatz, M. S. (1993). A diametric forces model of strategic change: Assessing the antecedents and consequences of restructuring in the higher education industry. Strategic Management Journal, 14(S1), 83-102.

Zhang, A., Zhang, Y., \& Zhao, R. (2001). Impact of ownership and competition on the productivity of Chinese enterprises. Journal of Comparative Economics, 29(2), 327-346. 